\title{
Erratum to: Resilience to global food supply catastrophes
}

\author{
Seth D. Baum ${ }^{1}$ - David C. Denkenberger ${ }^{2} \cdot$ Joshua M. Pearce $^{3,4} \cdot$ Alan Robock $^{5}$. \\ Richelle Winkler ${ }^{6}$
}

Published online: 2 August 2015

(c) Springer Science+Business Media New York 2015

\section{Erratum to: Environ Syst Decis (2015) 35:301-313 \\ DOI 10.1007/s10669-015-9549-2}

In the original publication, the affiliation of the co-authors, Joshua M. Pearce and Alan Robock, was incorrect. The correct affiliation is given with this erratum.

The online version of the original article can be found under doi:10.1007/s10669-015-9549-2.

Seth D. Baum

seth@gcrinstitute.org

David C. Denkenberger

david.denkenberger@colorado.edu

Joshua M. Pearce

pearce@mtu.edu

Alan Robock

robock@envsci.rutgers.edu

Richelle Winkler

rwinkler@mtu.edu

1 Global Catastrophic Risk Institute,

PO Box 40364, Washington, DC 20016, USA

2 Global Catastrophic Risk Institute, 2345 Forest Avenue, Durango, CO 81301, USA

3 Department of Materials Science and Engineering, Michigan Technological University, 601 M\&M Building, 1400 Townsend Drive, Houghton, MI 49931, USA

4 Department of Electrical and Computer Engineering, Michigan Technological University, 601 M\&M Building, 1400 Townsend Drive, Houghton, MI 49931, USA

5 Department of Environmental Sciences, Rutgers University, 14 College Farm Road, New Brunswick, NJ 08901, USA
6 Department of Social Sciences, Michigan Technological University, Houghton, MI, USA 